\title{
Aerodynamic Characteristics and Fuze Arming Time Determination of Anti-Armour Aviation Bomb
}

\author{
Zoran Novaković1 \\ Momčilo Nikolić ${ }^{1)}$ \\ Stevan Kozomara ${ }^{1)}$
}

\begin{abstract}
Aerodynamic coefficients of the anti-armour aviation bomb (AAAB) are determined in subsonic and transonic flow field regimes in the wind tunnel. These flow conditions directly affect the fuze arming mechanism time of the bomb. An alternative and reliable method for the fuze arming time measuring in relation to the expensive flight tests is defined in the paper. Verification of the method will be performed in the real flight conditions after the wind tunnel testing.
\end{abstract}

Key words: aviation bomb, anti-armour aviation bomb, fuze arming, aerodynamic performances, aerodynamic coefficients, aerodynamic testing, wind tunnel.

\section{Nomenclature}

\begin{tabular}{|c|c|}
\hline$\left(x_{a}\right)_{t}$ & - aircraft position at instant $\mathrm{t}$ \\
\hline$\left(x_{a}\right)_{t 1}$ & - aircraft position at instant $t_{1}$ \\
\hline$v_{a}$ & - aircraft velocity \\
\hline$v_{t}$ & - aviation bomb velocity at instant $t$ \\
\hline$v_{t 1}$ & - aviation bomb velocity at instant $t_{1}$ \\
\hline 2 & - aviation bomb velocity at instant $t_{2}$ \\
\hline$v_{y 0}$ & $\begin{array}{l}\text { - aviation bomb orthogonal initial velocity at } \\
\text { instant } t_{0}\end{array}$ \\
\hline & - aircraft minimum level flight altitude \\
\hline$d_{t 1}, d_{t}, d_{t 2}$ & $\begin{array}{l}- \text { distances between aircraft and the bomb at } t_{1} \text {, } \\
t \text { and } t_{2} \text { respectively }\end{array}$ \\
\hline$d_{C R}$ & $\begin{array}{l}\text { - critical distance between aircraft and aviation } \\
\text { bomb }\end{array}$ \\
\hline & - fuze arming time \\
\hline$t_{F}$ & - the instant when air bomb impact target \\
\hline$x_{t F}$ & - aviation bomb range coordinate \\
\hline. & - the number of arming vane revolutions \\
\hline & - dominant frequency \\
\hline$i$ & - angle of attack index \\
\hline a & - angle of attack \\
\hline$C x$ & - drag force coefficient \\
\hline$C y$ & - side force coefficient \\
\hline$C z$ & - lift force coefficient \\
\hline $\mathrm{Cl}$ & - rolling moment coefficient \\
\hline $\mathrm{Cm}$ & - pitching moment coefficient \\
\hline $\mathrm{Cn}$ & - yawing moment coefficient \\
\hline$M$ & - Mach number \\
\hline
\end{tabular}

\section{Introduction}

IRCRAFT that attacks a target at the low level flying, for its own security, has to do it and leave the target area as quickly as possible due to the growing efficiency of air defense systems. Since the aircraft flying level is low (up to $100 \mathrm{~m}$ from the ground), the aviation bomb explosion on the target or accidental air bomb explosion on its ballistic path could endanger the aircraft. Therefore, aviation bombs should be retarded on their ballistic trajectories, with the precise reproductive fuze arming mechanism time.

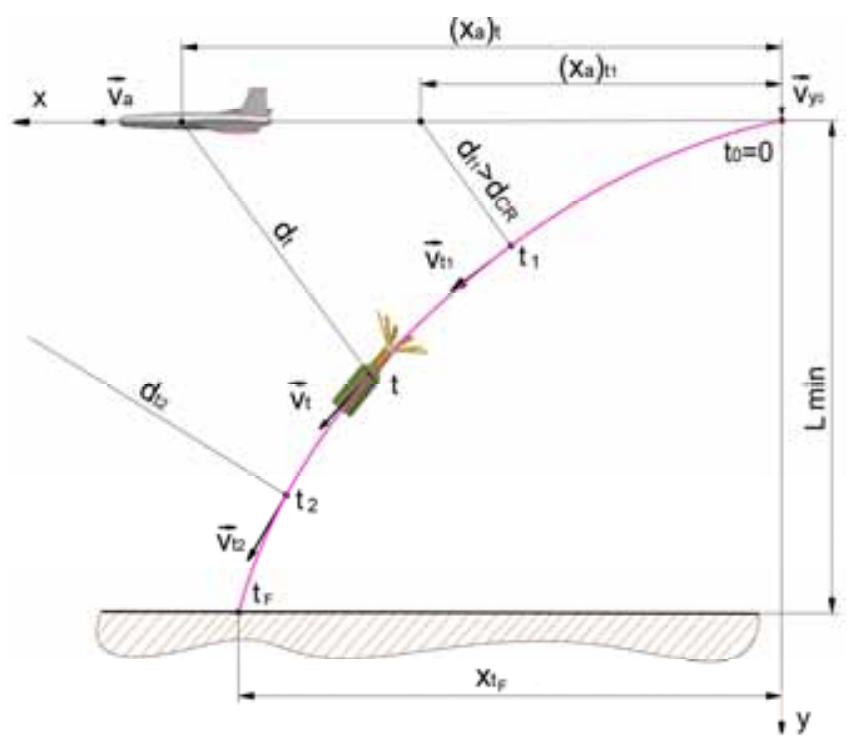

Figure 1. Time dependence of the distance between aircraft and AAAB.

Self-developed and realized prototype lot of anti-armour aviation bombs (AAAB) has been tested in the wind tunnel in order to confirm the projected fuze arming mechanism time (0.7-1.5) $s$, [1]. Also, it gives possibility to make some necessary design corrections of all AAAB samples before starting the expensive flight tests.

For a given type of aircraft the values of the minimum low level flight altitude $L_{\min }$ were assumed, as well as the flightspeed during the bombing in the range of $v_{a}=(180-310) \mathrm{m} / \mathrm{s}$ and for the designed (numerical predictions) aviation bomb

\footnotetext{
1) Military Technical Institute (VTI), Ratka Resanovića 1, 11132 Belgrade, SERBIA

Correspondence to: Zoran Novaković; e-mail: novakoviczoca@gmail.com
} 
aerodynamic coefficients the bomb ballistic trajectories were calculated, but it is not the subject of the paper. An analysis of the aviation bomb ballistic trajectory has determined the timedependence of the distance between aircraft and aviation bomb, as shown in Fig. 1 .

The bombs are ejected from the aircraft under-wing container by the initial rate that represents a vector sum of the horizontal speed of the aircraft $v_{a}$ and vertical speed $v_{y 0}$, given by a mechanism for impulse rejection. Then, rotation of the fuze arming mechanism vane is activated. At the same time, the body tail fins placed around the bomb body are instantly deployed around the vane perimeter to slow the bomb along its ballistic trajectory and to stabilize it.

Anti-armour bomb fuze is of a percussion type, with initial chain interruption, remote-temporal arming and selfdestroying. The fuze should not be armed before the time $t_{l}$ expires, and a safe distance $d_{C R}$ between the aircraft and airbomb is achieved, according to the criteria prescribed by [2]. The fuze arming time $t$ horologe measured from the instant of the pilot cockpit trigger press is acceptable within the interval $\left(t_{1}, t_{2}\right)$. In addition, the fuze arming time must be less than the time $t_{F}$ when the air bomb hits the target.

Fuze arming time $t$ is the sum of the four values:

$$
t=T_{1}+T_{2}+T_{3}+T_{4}
$$

$T_{1}$-aircraft electrical installation relays execution time,

$T_{2}$-execution time of the impulse rejecting mechanism,

$T_{3}$-fuze arming mechanism execution time

$T_{4}$-fuze firing pin above the percussion primer relocation time

The $T_{1}, T_{2}$ and $T_{4}$ times are of the order of milliseconds, while the $T_{3}$ time is of the order of seconds. These first three values $\left(T_{1}, T_{2}\right.$ and $\left.T_{4}\right)$ can be ignored in comparison to $T_{3}$, because they are smaller for three orders of magnitude.

Therefore, in the first approximation, it can be approved that the total arming time $t$ is equal to the fuze arming mechanism execution time $T_{3}$.

$$
t \approx T_{3}, t \in\left(t_{1}, t_{2}\right) .
$$

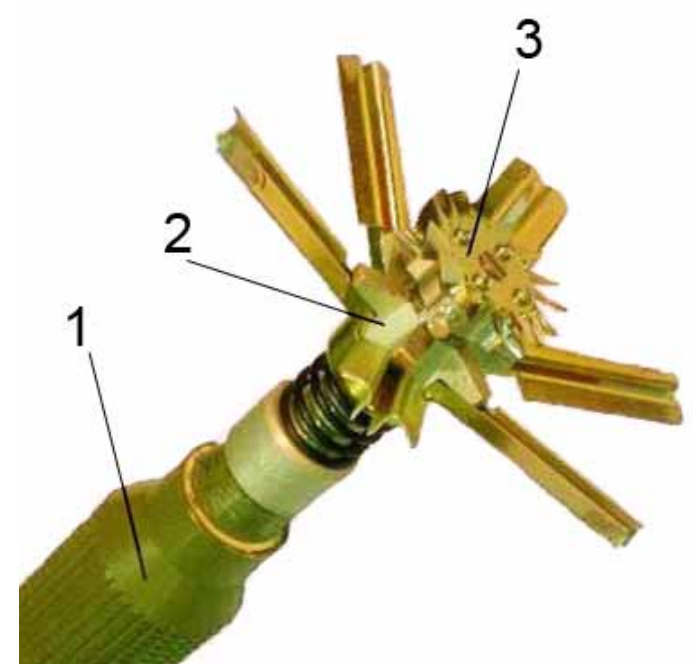

Figure 2. Aviation bomb test model (disarmed original AAAB) 1-bomb body, 2-stabilizer tail unit with folding fins, 3-arming vane with centrifugal safety pins

The model of the bomb, which is tested in the wind tunnel, was a disarmed original anti-armor aviation bomb. This model is suited for two types of tests:

1. Aerodynamic forces and momentum measurements on model configuration using tensiometric air-balance without arming vane mechanism (Fig.3),

2. Vane rotational speed (number of revolutions $n$ ) and fuze arming execution time $T_{3}$ measurements, from the moment of the vane unlock, when the desired Mach number in the wind tunnel is reached, until the vane separation from the tail stabilizer unit (Fig.4).

Both types of the wind tunnel tests have been carried out in the range of characteristic Mach numbers, between 0.6 and 0.9 , [3]. In this way, the interval of aircraft velocities between 180 and $310 \mathrm{~m} / \mathrm{s}$ is covered.

The model of the anti-armour aviation bomb for the wind tunnel testing is modified to be placed on the back holder and integrated with the sting-balance named ABLE MK XXV 1, [4]. The body of the anti-armour aviation bomb is cylindrical with the same diameter nose flat base. Since the test model represents the disarmed $\mathrm{AAAB}$, its shape is geometrically and aerodynamically identical to the original (Fig.2). At the rear side of the cylindrical anti-armour aviation bomb there are six peripherally located and symmetrically arranged folding fins. They make a stabilizer tail unit (2), (Fig.2). The freely rotating arming vane mechanism (3) is located behind the stabilizer.

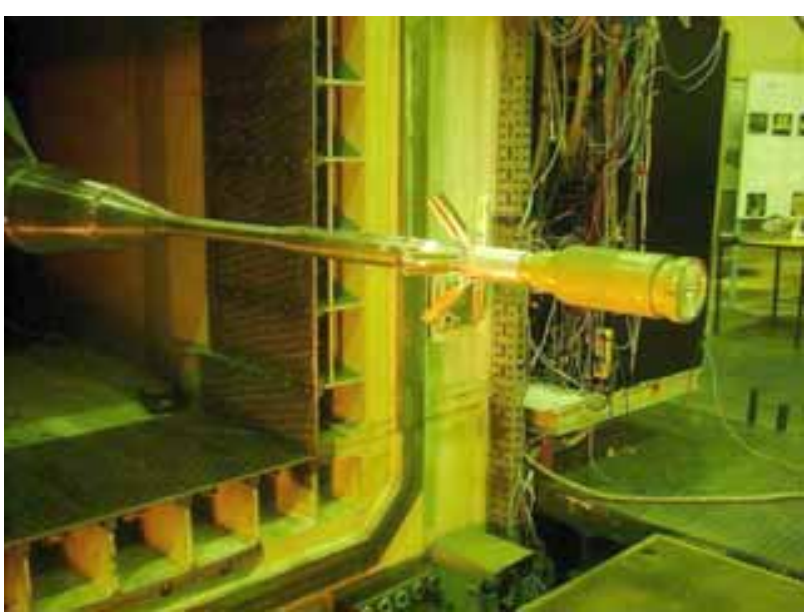

Figure 3. Aviation bomb test model on a straight line sting

\section{Method of Measurement and Data Processing}

Measurements of aerodynamic forces, moments and fuze arming mechanism execution times have been carried out in a trisonic wind-tunnel T-38 in the Military Technical Institute in Belgrade, Serbia, [5]. For the aerodynamic forces and moments measurements the ABLE tenzo-metric sixcomponent sting-balance was used (Fig.3). The base drag of the model has not been corrected. On the sting-balance the following features were measured: axial component, normal component, lateral force, pitching moment, yawing moment and rolling moment. In addition to the axial component, which was the basic measured feature, other properties were measured $\left(C_{y}, C_{z}, C_{l}, C_{m}, C_{n}\right)$, although it was not a requirement of the test. The results of their measurements are shown in Table 1 and Table 2 in form of the aerodynamic coefficients dependence vs. the angle of attack.

Measurements of the ballistic functional properties (time $\left.\mathrm{T}_{3}, n\right)$ were conducted on a sting in form of a broken line (Fig.4), with an elbow angle of 15 degrees. Both tests were conducted in the transonic section of the wind-tunnel. The flow velocity approximately corresponded to the Mach numbers $M=0,6 \div 0,9$. TELEDYNE acquisition system was used for data collection. VAX 11/780 computer and standard software package were used for data processing. 


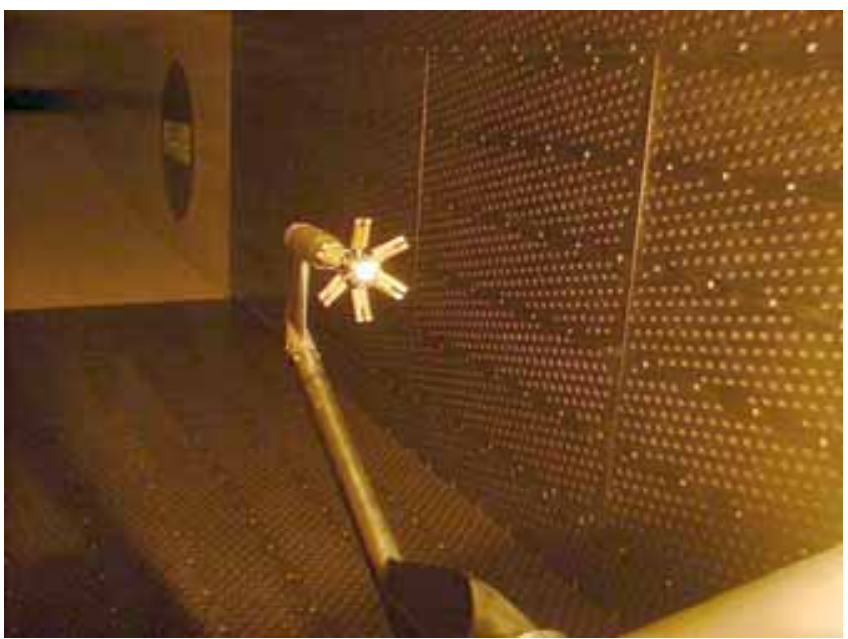

Figure 4. Aviation bomb test model on a broken line sting

A small tube, whose task was to measure the arming vane rotating speed and its separation time, $T_{3}$, was built into the aviation bomb body. One end of the tubing is positioned under the rotating arming vane. When each of the four centrifugal safety pins passes over the tubing, the air pressure at the end of the tubing is changed. Therefore, due to the rotation of arming vane the cyclic pressure changes are registered. When it comes to the arming vane separation, a differential pressure sensor (PRT), embedded into the airbomb body, registers an average pressure jump (Fig.5).

The arming vane rotation number $n$ is obtained as the quotient of the dominant frequency $f$ and the number of centrifugal safety pins $N$ :

$$
n=\frac{f}{N}
$$

For the transducer filtering, in accordance with the expected arming vane rotation number $\left(3000 \mathrm{~min}^{-1}\right)$ that was estimated before the wind tunnel tests, a $1000 \mathrm{~Hz}$ filter is chosen. A velocity of $200 \mathrm{~m} / \mathrm{s}$ has been achieved, which approximately corresponds to the Mach number of $M=0.6$. On the basis of the resulting dominant frequency $f=192 \mathrm{~Hz}$, the rotation number of arming vane is calculated:

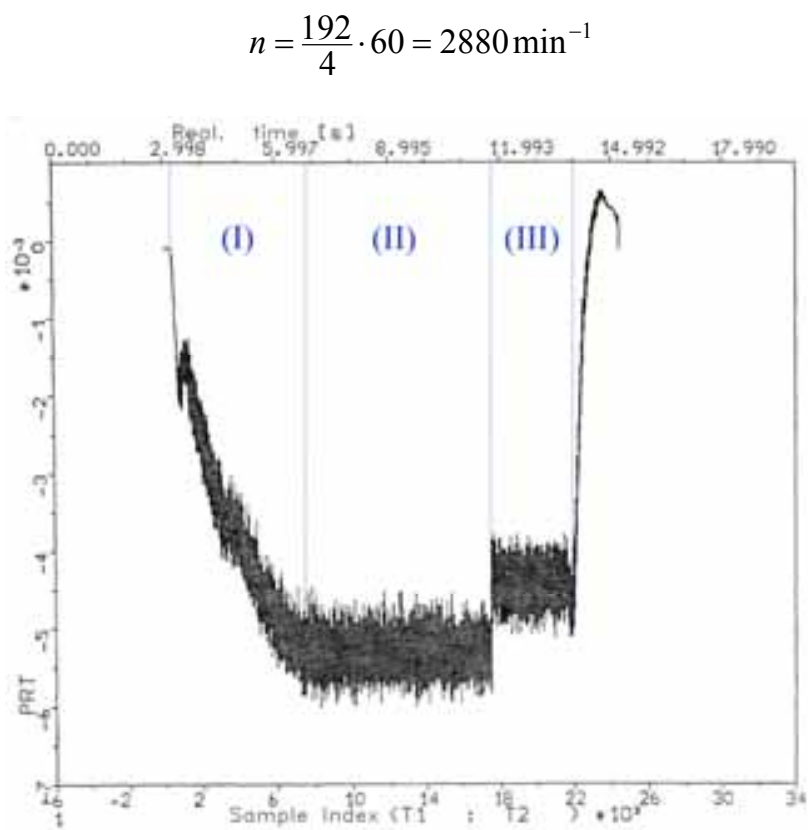

Figure 5. Plotted Diagram of Pressure Changing Frequency (I) - airflow acceleration, (II) - $\mathrm{T}_{3}$ time, (III) - arming vane separation (fuze arming)

\section{Test Results}

By matching the values of $C_{x}$ columns, for the complete model (Table 1) and blunt body model configuration (Table 2), the following can be concluded: except of the AAAB stabilization on its trajectory, the stabilizer fins also represent the air-brake which has a dominant (in relation to influence of bomb nose flat base) role in reducing the speed of AAAB, in order to allow it to hit the target and to explode a little later when the aircraft reaches the safe zone.

Table 1. Complete Model

\begin{tabular}{|c|c|c|c|c|c|c|c|c|}
\hline \multicolumn{9}{|c|}{ Wind Tunnel T-38 } \\
\hline \multicolumn{9}{|c|}{ WIND TUNNEL TESTING OF ANTI-ARMOUR BOMB } \\
\hline \multicolumn{2}{|c|}{$\begin{array}{l}\text { AAAB01 } \\
\text { testing }\end{array}$} & \multicolumn{2}{|c|}{$\begin{array}{c}\text { Sequence number } \\
\text { of blowing: } 1\end{array}$} & & & & & \\
\hline \multicolumn{9}{|c|}{ Model Configuration - Complete Model } \\
\hline $\mathbf{i}$ & a & M & $\mathbf{C x}$ & Су & $\mathbf{C z}$ & Cl & $\mathbf{C m}$ & Cn \\
\hline 1 & -0.10 & 0.604 & 4.4053 & 0.020 & -0.010 & -0.0029 & 0.077 & -0.0890 \\
\hline 2 & 1.96 & 0.604 & 4.3549 & 0.053 & 0.190 & -0.0101 & -1.175 & -0.1967 \\
\hline 3 & 3.98 & 0.604 & 4.3895 & 0.098 & 0.249 & -0.0098 & -1.792 & -0.0098 \\
\hline 4 & 5.96 & 0.604 & 4.4307 & 0.113 & 0.228 & -0.0149 & -2.098 & -0.0490 \\
\hline 5 & 8.00 & 0.603 & 4.4850 & 0.119 & 0.215 & -0.0267 & -2.289 & -0.0741 \\
\hline 6 & 10.03 & 0.603 & 4.5486 & 0.123 & 0.199 & -0.0281 & -2.479 & -0.0688 \\
\hline
\end{tabular}

Due to the increased resistance of the stabilizer fins, drag coefficients measured at the sting-balance have the highest values, $C_{x}$ (Table 1 ), which were ever measured in the wind tunnel T-38 for the aviation bombs. Likewise, the explanation of the stabilizer fins dominant influence with its higher resistance is obtained by comparing the results with a similar model without stabilizer fins, [6], [7]. Similar to the results of measurements in the reference wind tunnels in the world [5], the expected value of drag coefficient $C_{x} \approx 0,8 \div 0.9$ (Table 2) was confirmed on the model without stabilizer tail unit with folding fins (Blunt Body Model).

The measured value for the fuze arming mechanism execution time, $T_{3} \approx 5 \mathrm{~s}$, did not coincide with the expected value (0.7-1.5) s [1], for two reasons:

1. In the real flight conditions, when the aviation bomb is ejected from the aircraft, the arming vane instantaneously enters an airflow that corresponds to the actual speed of the aircraft, with the adequate value of the Mach number. This value of the Mach number we want to achieve in the wind tunnel. However, in the test, the wind tunnel is not capable to achieve this value of the Mach number instantaneously with consequence: zone (I) - Airflow Acceleration, Fig.5. Hence, in the initial phase of the experiment, the flow conditions are not equal to the real.

2. One arming vane was used in several tests in the wind tunnel. Although it is possible to use it in a number of tests, the mechanism of the arming vane is not constructively designed for the repeated use.

For those reasons, in order to obtain better results, the reconstruction of the existing test model was made and new tests with different model samples were prepared, Fig. 6. Each model was used only for one experiment. Reconstruction of the model is made so that the movement of arming vane begins at the moment when the desired pressure in the wind tunnel is achieved, as well as the required Mach number, corresponding to the real flight conditions. The aviation bomb was disassembled, and the electro-magnets (I and II) were arranged in its interior, Fig.6. Their lifter (6) and locking fork (7) lock or unlock the rotation of the arming vane (1). Electro-magnet I, by its lifter and locking fork, hold the arming vane blocked during the acceleration of the 
air-flow in the wind tunnel, up to the moment when the desired Mach number is achieved. After that, the first electro-magnet (I) stops, and the second one (II) pulls the lifter and locking fork back, in order to unlock the arming vane, which starts to rotate at the moment when the Mach number reaches the desired value in the wind tunnel. This corresponds to the real conditions of use.

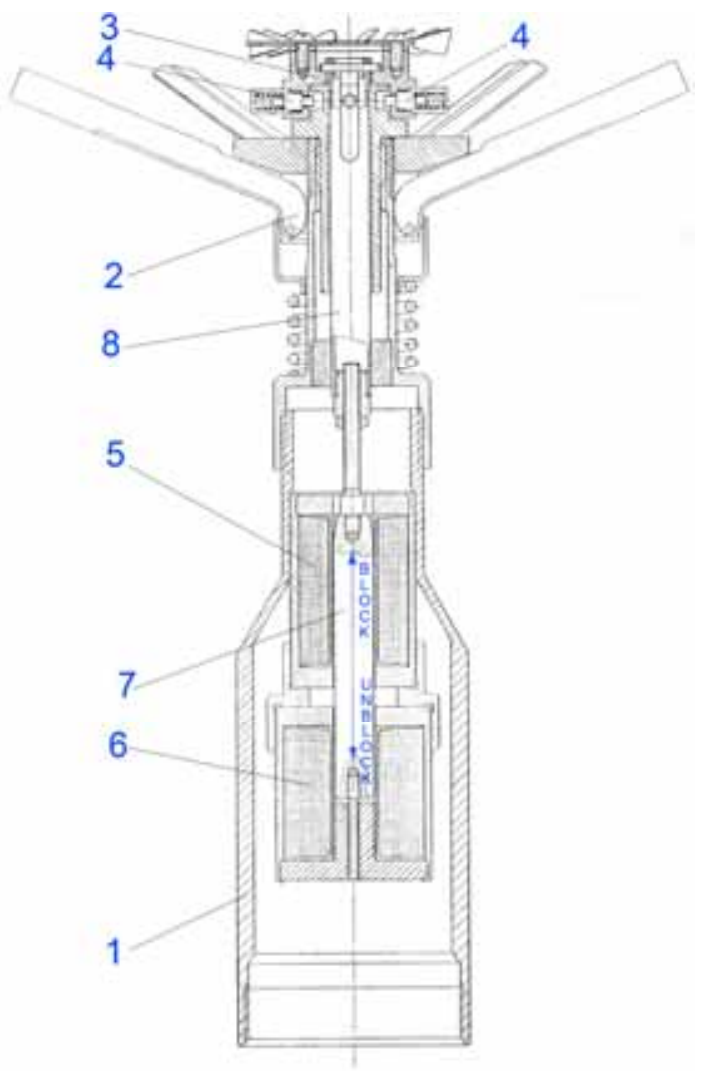

Figure 6. Redesigned Aviation Bomb Test Model (cross section)

1-bomb body, 2-stabilizer tail unit with folding fins, 3-arming vane, 4centrifugal safety pins, 5-electro-magnet I, 6- electro-magnet II, 7-lifter, 8locking fork

Table 2. Blunt Body Model

\begin{tabular}{|c|c|c|c|c|c|c|c|c|}
\hline \multicolumn{9}{|c|}{ Wind Tunnel T-38 } \\
\hline \multicolumn{9}{|c|}{ WIND TUNNEL TESTING OF ANTI-ARMOUR BOMB } \\
\hline \multicolumn{2}{|c|}{$\begin{array}{l}\text { AAAB01 } \\
\text { testing }\end{array}$} & \multicolumn{2}{|c|}{$\begin{array}{l}\text { Sequence number } \\
\text { of blowing: } 4\end{array}$} & & & & & \\
\hline \multicolumn{9}{|c|}{ Model Configuration - Blunt Body Model } \\
\hline $\mathbf{i}$ & a & $\mathbf{M}$ & $\mathbf{C x}$ & $\mathbf{C y}$ & $\mathbf{C z}$ & $\mathbf{C l}$ & $\mathbf{C m}$ & Cn \\
\hline 1 & -0.10 & 0.298 & 0.7730 & 0.051 & 0.020 & 0.0025 & 0.027 & 0.0149 \\
\hline 2 & 1.98 & 0.298 & 0.7761 & 0.060 & 0.022 & 0.0033 & -0.015 & 0.0110 \\
\hline
\end{tabular}

\begin{tabular}{|c|c|c|c|c|c|c|c|c||}
\hline 3 & 3.95 & 0.298 & 0.7938 & 0.085 & 0.022 & 0.0038 & -0.012 & 0.0170 \\
\hline 4 & 5.96 & 0.298 & 0.8144 & 0.083 & 0.018 & 0.0047 & 0.022 & 0.0180 \\
\hline 5 & 7.98 & 0.296 & 0.8537 & 0.050 & 0.040 & 0.0046 & 0.044 & 0.0164 \\
\hline 6 & 10.02 & 0.296 & 0.8827 & 0.038 & 0.087 & 0.0045 & 0.064 & 0.0169 \\
\hline
\end{tabular}

\section{Conclusion}

The results $\left(C_{x}\right.$, Table 1$)$ obtained, with the calculated ballistic trajectories show that the aircraft can carry out the bombing safely, with speeds $v_{a}=(180-310) \mathrm{m} / \mathrm{s}$, and altitudes less than $100 \mathrm{~m}$. The result $\left(T_{3} \approx 5 \mathrm{~s}\right)$ obtained with the first test model (Fig. 2) is the same order of magnitude as referenced $(0.7-1.5) \mathrm{s},[1]$.

The new upcoming series of tests of the redesigned aviation bomb test model in the wind tunnel are arranged. For these new tests a sufficient number of model samples is provided. The purpose of these experiments is to get a functional dependence of the arming vane rotation number to surrounding streamlines speed of redesigned bomb test model (Fig. 6). If the expected test results in the wind tunnel with the reconstructed test model of the air bomb were confirmed by the results of flight tests with the realistic aviation bombs, the test procedure in the wind tunnel could be adopted as a reliable method for the fuze arming mechanism time determination.

\section{References}

[1] Tehnički opis i odredbe pripreme za upotrebu PTAB 2.5, SSNOVazduhoplovnotehnička uprava JNA, 1994., (prevod sa ruskog)

[2] Savezni sekretarijat za narodnu odbranu SFRJ.: Borbena upotreba vazduhoplovnih sredstava pri dejstvu po ciljevima na kopnu i moru, 1988., knjiga I.

[3] ETKIN,B.: Dinamika poleta, Moskva, 1964, Masinostroenie.

[4] ANASTASIJEVIĆ,Z., MARINKOVSKI,D., SAMARDŽIĆ,M.: Merenje aerodinamičkih derivativa stabilnosti $u$ aerotunelima. Kumulativna naučnotehnička informacija, Military Technical Institute, Belgrade, SERBIA, 2001, No.3.

[5] AIAA Standards. AIAA Recommended practice for calibration and use of internal strain-gauge balances with application to wind tunnel testing. AIAA-R-091-2003e, ISBN: 978-1-56347-646-4, Virginia, 2003.

[6] HOERNER,S.F.: FLUID-Dynamic Drag, 1965. http:/www.greenbookee.net/hoerner-1965-fluid-dynamic-drag/

[7] FINCK,R.D.: USAF Stability and Control Datacom, Final Report, AFWAL-TR83-3048, April. 1978 http://oai.dtic.mil/oai/oai?verb=getRecord\&metadataPrefix $=$ html\&id entifier $=\mathrm{ADB} 072483$.

\title{
Određivanje aerodinamičkih karakteristika i vremena armiranja upaljača protivoklopne avio-bombe
}

\begin{abstract}
Aerodinamički koeficijenti protivoklopne avio-bombe se određuju u subsoničnom i transoničnom režimu strujanja u aerotunelu. Ovi uslovi opstrujavanja direktno utiču na vreme armiranja upaljača protivoklopne avio-bombe. $U$ radu se definiše alternativna i pouzdana metoda za merenje vremena armiranja upaljača u odnosu na skupa letna ispitivanja. Nakon aerotunelskih ispitivanja, kao verifikacija ove metode, predviđena su letna ispitivanja vremena armiranja upaljača u realnim uslovima.
\end{abstract}

Ključne reči: avionska bomba, protivoklopna bomba, armiranje upaljača, aerodinamičke karakteristike, aerodinamički koeficijenti, aerodinamičko ispitivanje, aerodinamički tunel. 


\title{
Определение аэродинамических характеристик и времени укрепления зажигалки противотанковой авиабомбы
}

\author{
Аэродинамические коэффициенты противотанковой авиабомбы определяются в дозвуковом и трансзвуковом \\ режимах течения в аэродинамической трубе. Эти условия течения непосредственно влияют на время укрепления \\ зажигалки противотанковой авиабомбы. В работе определяются альтернативный и надёжный способы для \\ измерения времени усиления зажигалки по сравнению с набором лётных испытаний. После испытаний в \\ аэродинамической трубе, как проверка этого метода, планируются лётные испытания времени укрепления \\ зажигалки в реальных условиях.
}

Ключевые слова: авиабомба, противотанковая бомба, усиливание зажигалки, аэродинамические характеристики, аэродинамические коэффициенты, аэродинамические испытания, аэродинамическая труба.

\section{Détermination des caractéristiques aérodynamiques et du temps de renforcement du fusée pour la bombe antichar aéroportée}

\begin{abstract}
Les coefficients aérodynamiques d'une bombe antichar aéroportée se déterminent dans la soufflerie aérodynamique sous le régime subsonique et transsonique du courant. Ces conditions du courant affectent directement sur le temps de renforcement de fusée chez la bombe antichar aéroportée. Dans ce travail on définit une méthode alternative et fiable pour le mesurage du temps de renforcement de fusée par rapport aux essais en vol qui sont très coûteux. Après les essais dans la soufflerie aérodynamique, comme la vérification de cette méthode, on a prévu les essais en vol pour le temps de renforcement de fusée dans les conditions réelles.
\end{abstract}

Mots clés: bombe aéroportée, bombe antichar, renforcement de fusée, caractéristiques aérodynamiques, coefficients aérodynamiques, essai aérodynamique, soufflerie aérodynamique 